\title{
Work from Home Proclivity: A Year into Covid-19 Pandemic
}

\author{
Daniella C. Sampepajung ${ }^{*}$, Insany Fitri Nurqamar', Muhammad Nurhadi $\mathbf{N}^{\mathbf{2}}$ \\ ${ }^{1}$ Faculty of Economics and Business, Universitas Hasanuddin, Makassar, Indonesia \\ ${ }^{2}$ STIE Amkop Makassar, Makassar, Indonesia \\ *daniellacynthia@unhas.ac.id
}

\begin{abstract}
All forms of formal education were abruptly shifted into online-learning when Covid-19 hit globally. This unexpected change has forced education practitioners to adapt and conduct their work remotely in order to minimize the virus spread. However, sudden changes are seldom arduous and work from home came with its many challenges. This research seeks to examine the working conditions and job requirements, the time and task management, work related stress, performance at work lecturer's experience during online-learning and their inclination towards work from home. in the future. This research is an exploratory study and the data is analyzed with a statistic descriptive method to describe the phenomenon. Using online questionnaire, a total of 120 lecturers responded. The study discovers that lecturers find the conditions of work from home. to be acceptable, they are able to organize their task and time to some extent, and it does not affect their work performance and does not have a negative impact on their stress level. In the future, the lecturers will feel neutral about work from home. after the pandemic subsidence. More are leaning towards going back to work in office settings, but open to do hybrid-working, which is a combination of work from office and work from home. .
\end{abstract}

Keywords: Job Requirements, Task Management, Working Conditions, Work From Home, Work Related Stress

\section{INTRODUCTION}

The Covid-19 virus brings extensive impact on numerous aspects of everyday life, including the changes in personal as well as professional setting. Due to its contagious behavior through droplets to smaller aerosols, the World Health Organizations (WHO) has recommended governments to impose socialdistancing in order to slow the spread of the disease (Sheng, 2020; WHO, 2020). In order to conduct social distancing, almost every company and education institutions from all over the world issued a work from home. (WFH) policy.
The work from home. policy itself is not a novel concept. Since the 1980s, workers have worked remotely during business travels, for instance (Faulds \& Raju, 2021). In the beginning, only certain type of jobs can be done remotely. Studies suggest that workers voluntarily worked remotely for certain purposes, for example, due to domestic responsibilities (Bloom, 2014; Versey, 2015), in order to reduce commuting (Kelliher \& Anderson, 2010), working flexibility as well as positive impact for the environment (Hickman \& Robison, 2020), or with the purpose to avoid distractions (Delanoeije, Verbruggen, \& Germeys, 2019). With the 
current massive development of Information Communication Technology (ICT), working outside formal office environment has become easier. (Nie \& Erbring, 2002).

Nicholson and Baruch (1997) suggested that work from home. suits the type of jobs with high degree or cerebral work, which is done as an individual with explicitly defined job areas, includes moderate degree of initiative, the outputs and success indicators are measurable, and do not require bulky equipment. To some extent, the characteristics of lecturer as a job fits these criteria. The Four Factors of Telework is a framework developed by Nicholson and Baruch (1997) where the home/work interface, the job, the individual, and the organization are needed to work effectively. This study examines three of these factors: the home/work interface and the job in the working conditions and requirements section. The individual factor is examined by asking about time and task management, work related stress, and performance at work. The organizational realm is not examined in this research because in the time of the research, the work from home. policy are regulated by the government due to the pandemic and not by choice.

Previous studies discover that remote working or working not in formal office environment comes with various disadvantages such as longer workhours and attending more meetings (Hill, Miller, Weiner, \& Colihan, 1998; Jackson, 1999; Kost, 2020), as well as home office constraints, work uncertainties, and inadequate tools (Ipsen, van Veldhoven, Kirchner, \& Hansen, 2021), and could also lead to difficulty to separate home and professional concerns (Klopotek, 2017). Azcel et al (2021) indicated that work from home. is not advantageous for researchers. Another challenge of working-from-home is the difficulty to divide professional and home concerns since boundaries become blurry (Gurstein, 2001; Hartig, Kylin, \& Johansson, 2007; Klopotek, 2017; Kost, 2020). On top of that, working at home means there is an added pressure of domestic responsibilities, and the distractions at home such as the presence of young children in the family (Bloom, 2014; Larson, Vroman, \& Makarius, 2020; Versey, 2015; Waizenegger, McKenna, Cai, \& Bendz, 2020).

However, recent study by Susilo (2020) argues that work from home. increase work motivation. Work from home. also have many benefits such as work-life balance, improved work efficiency, and greater work control (Ipsen et al., 2021). In addition, work from home. means more flexible working hours and saving time on commute to work (Dizaho, Salleh, \& Abdullah, 2017; Klopotek, 2017; Purwanto et al., 2020). Academics indicate that working in the office is better for collecting data and integrating with colleagues, while working at home are better for reading literature, working on manuscript, and analyze their data (Aczel, Kovacs, Van Der Lippe, \& Szaszi, 2021).

In response the Covid-19 virus threat, working via digital communications method has been adopted by organizations all over the world (Belzunegui-Eraso \& Erro-Garcés, 2020). On march 2020, the Directorate of Higher Education of Indonesian Ministry of Education instructed all high education institutions in the country to conduct teaching and learning process from home through online facilities (KEMDIKBUD, 2020). The decision resulted in thousands of lecturers in Indonesia to carry out their Tri Dharma Pendidikan responsibilities (education, research, and community service) remotely. In addition, lecturers with additional responsibilities such as those with administrative positions, committee members, journal editors, et cetera, need to work from home. as well. The lecturers, like many other professions, needed to abruptly change their working habit while maintain the same quality of work despite the challenges.

Before the pandemic, the were only $10 \%$ of workers whom worder remotely and only $20 \%$ work from home on certain days (Faulds \& Raju, 2021). Whereas during the pandemic, especially before countries met their vaccination target, $52 \%$ of workers all over the globe work from home. (Lidwina, 
2021). In other part of the globe, work from home. got overwhelming positive reactions and some companies has even issue work from home. as a permanent policy (McDonagh, 2021; Stoller, 2021; Vyas \& Butakhieo, 2021)

The work from home. policy precipitated pros and cons amongst academics because the policy not only shifted face to face learning to individual learning, it also limits other education process. Laboratory activities, thesis consultations, and other academics services were also delayed. Workers, in this case lecturers, were forced to adapt to technology facilities to conduct online learning. However, the ability to adapt to technological media is crucial for each individual. Academics are required to quickly understand how to use new learning medias or use existing technology in new and creative ways (Waizenegger et al., 2020). In addition, the were the added pressure of managing a home environment that may not match work objectives.

Considering the increase cases of Covid-19 in Indonesia as well as the vaccination program which has not reach the majority of the country's populations (Umah, 2021) when this research was conducted, the work from home. policy seemingly will continue in the foreseeable future. On the other hand, high education plays a pivotal part in the continuity of modern civilization. The implementation of the policy could be a longterm shift when considering the possibility of a prolonged or repeated outbreak is becoming a new culture that forces workers to use technology and accept alternative job adjustments (Kramer \& Kramer, 2020).

The proclivity or tendency for lecturers to do work from home. regularly after the pandemic gradually ease out our life is looked into in the study. This study delineates the exploration on how lecturers are facing the changes and how they maintain "business as usual" during this pandemic from 5 aspects: working conditions and job requirements; time and task management; work related stress; performance at work; and proclivity to work from home. in the future.

\section{METHOD}

This research was conducted using online surveys, distributed directly to lecturers and through numerous lecturers WhatsApp group messaging as well as other social media platforms such as Instagram and Facebook in May 2021. The respondents are lecturers from high education institutions in Makassar and the survey was conducted three semesters into the pandemic. The survey included the study information and the anonymity of the collected data. There were preliminary questions entailed to confirm the respondent's occupation, home-based institution, and have experienced both offline and online working in their respective universities. The last aspect is needed to ensure that the respondents can compare their experience of face-to-face and virtual teaching and learning process.

According to Hair et al (2010), minimum sample size is 100 respondents since excessively large sample size will hinder getting suitable model (Hair, Ringle, \& Sarstedt, 2013). For this reason, it is suggested that the appropriate sample size is within 100-200 respondents. Therefore, the sample size for this study is 120 Makassar based lecturers.

The survey was designed to inscribed the experience of virtual working for lecturers in high educations. It includes 39 questions on five sections that covered work from home. experience: working conditions and job requirements; time and task management; work-related stress; work performance; and decisions to work from home. in the future. The respondents disclose the extent to which they agreed to the variables applicable to their current settings using a five-point Likert scale: strongly disagree, disagree, neutral, agree, and strongly. First, the results are described and compared with previous work from home. studies. After that, the variables are compared with some distinct characteristics.

The work from home. lecturers experience during the pandemic were explored using the following survey questions. 
Table 1. Questionnaire Questions

\begin{tabular}{|c|c|}
\hline \multicolumn{2}{|r|}{ Working Conditions and Job Requirements } \\
\hline $\mathrm{X} 1.1$ & $\begin{array}{l}\text { I have adequate space to work at home } \\
\text { and support me to work from home. } \\
\text { optimally }\end{array}$ \\
\hline $\mathrm{X} 1.2$ & $\begin{array}{l}\text { I seldom experience failure internet } \\
\text { connection when working-from-home }\end{array}$ \\
\hline $\mathrm{X} 1.3$ & $\begin{array}{l}\text { I have adequate facilities (furniture, } \\
\text { gadgets, sound systems, and other tools) } \\
\text { to support me to work from home. }\end{array}$ \\
\hline $\mathrm{X} 1.4$ & $\begin{array}{l}\text { I have access to information and tools } \\
\text { required }\end{array}$ \\
\hline $\mathrm{X} 1.5$ & $\begin{array}{l}\text { Institution I work for provides sufficient } \\
\text { communication channels }\end{array}$ \\
\hline $\mathrm{X} 1.6$ & $\begin{array}{l}\text { Institutions I work for provide trainings } \\
\text { to work from home. }\end{array}$ \\
\hline $\mathrm{X} 1.7$ & I need more training to utilize ICT tools \\
\hline $\mathrm{X} 1.8$ & $\begin{array}{l}\text { I participate more meetings compared to } \\
\text { before the pandemic }\end{array}$ \\
\hline \multicolumn{2}{|r|}{ Time and Task Management } \\
\hline $\mathrm{X} 2.1$ & $\begin{array}{l}\text { I am able to separate time between work } \\
\text { and family }\end{array}$ \\
\hline $\mathrm{X} 2.2$ & $\begin{array}{l}\text { I have tended to family issues during } \\
\text { work hours }\end{array}$ \\
\hline $\mathrm{X} 2.3$ & $\begin{array}{l}\text { I feel hard maintaining work motivation } \\
\text { during business hours }\end{array}$ \\
\hline $\mathrm{X} 2.4$ & I have set aside "me-time" when needed \\
\hline $\mathrm{X} 2.5$ & I have set aside "me-time" when needed \\
\hline $\mathrm{X} 2.6$ & I never work on weekends \\
\hline $\mathrm{X} 2.7$ & $\begin{array}{l}\text { I feel the current workload is bigger than } \\
\text { before the pandemic }\end{array}$ \\
\hline $\mathrm{X} 2.8$ & $\begin{array}{l}\text { I am able to maintain same consistent } \\
\text { work schedule }\end{array}$ \\
\hline $\mathrm{X} 2.9$ & I experience time management problem \\
\hline \multicolumn{2}{|r|}{ Work-related Stress } \\
\hline $\mathrm{X} 3.1$ & $\begin{array}{l}\text { I feel less patient during work from } \\
\text { home. }\end{array}$ \\
\hline $\mathrm{X} 3.2$ & $\begin{array}{l}\text { I feel angry more easily during work } \\
\text { from home. }\end{array}$ \\
\hline $\mathrm{X} 3.3$ & $\begin{array}{l}\text { I complain more frequently during work } \\
\text { from home. }\end{array}$ \\
\hline $\mathrm{X} 3.4$ & $\begin{array}{l}\text { I experience "burn-out" syndrome during } \\
\text { work from home. }\end{array}$ \\
\hline $\mathrm{X} 3.5$ & $\begin{array}{l}\text { I feel more sensitive to work demand } \\
\text { during work from home. }\end{array}$ \\
\hline X3.6 & $\begin{array}{l}\text { Working-from-home make me more } \\
\text { stressed than usual }\end{array}$ \\
\hline X3.7 & I currently need more free time \\
\hline
\end{tabular}
Performance at Work
X4.1 I feel my work performance decrease during the pandemic

X4.2 I have sufficient digital skill prior to the pandemic

$\mathrm{X} 4.3$ I experience difficulties utilizing certain digital tools

X4.4 I experience difficulties adapting to work in "new normal

$\mathrm{X} 4.5$

I contact my supervisor every day during work from home.

$\mathrm{X} 4.6$

I feel noises at home affecting my work quality

X4.7 While working-from-home I often get distracted by digital entertainments

X4.8 I still feel integrated with my team/colleague although virtually

\begin{tabular}{cl}
\hline \multicolumn{2}{c}{ Decision to work from home. in the future } \\
\hline X5.1 $\begin{array}{l}\text { I am interested to continue work from } \\
\text { home. in the future }\end{array}$ \\
X5.2 $\quad \begin{array}{l}\text { I prefer to keep working-from-home if } \\
\text { my institutions-of-employment allow }\end{array}$ \\
X5.3 $\quad \begin{array}{l}\text { I am able to show better work } \\
\text { performance when working-from-home }\end{array}$ \\
\hline
\end{tabular}

Source: Primary Data (2021)

The analysis method this research employs is descriptive statistic, which is used to explain the conditions of work-form-home and the proclivity to continue doing so in the future. Descriptive statistics is a method related with collecting and presenting data in order to bear useful information and the data presented are easier to understand (Hasan, 2001; Walpole, 1995). Descriptive statistics are used to describe or to give explanation about the research object through sample or population (Sugiyono, 2007).

This study also looks into the respondents' answers about their work from home. experience with some of their characteristics. In working conditions and job requirements section, the results are compared with the institutions type. Time

Based on the data collected, this study describes the condition and challenges lecturers face doing work from home. during the pandemic and the decision about proclivity lecturers have to do work from home. in the future were reported. 


\section{RESULTS AND DISCUSSION}

The majority of the respondents are in the $30-40$ age group $(41,7 \%)$. Most of the respondents have more than two years of experience as lecturers, which seen from their functional position as assistant professor (Indonesian: asisten ahli 32,2\% and lektor $40,9 \%)$. Among the dataset, there was only one person $(0,9 \%)$ whom never did work from home. , while the majority of the respondents carried work from home. for more than 20 days a month $(44,3 \%)$. The work from home. frequency are varied among the respondents because Indonesia never imposed lockdown, only large and micro scale of social restrictions (Indonesian: Pembatasan Sosial Berskala Besar, Pembatasan Sosial Berskala Mikro). Although the government regulation mandated all classes to be held virtually, lecturers still to office albeit only a few days a month due to their structural positions or administrative necessities.

Table 2. Characteristics of Respondents

\begin{tabular}{|c|c|c|c|}
\hline Characteristics & Total & Characteristics & Total \\
\hline Age (years) & & \multicolumn{2}{|c|}{$\begin{array}{l}\text { Work from home. } \\
\text { frequency (days in a } \\
\text { month) }\end{array}$} \\
\hline$<30$ & $2.6 \%$ & $>20$ & $44.3 \%$ \\
\hline $30-40$ & $41.7 \%$ & $11-20$ & $38.3 \%$ \\
\hline $41-50$ & $26.1 \%$ & $1-10$ & $16.5 \%$ \\
\hline $51-65$ & $28.7 \%$ & 0 & $0.9 \%$ \\
\hline \multirow{2}{*}{$>65$} & $0.9 \%$ & & \\
\hline & & \multicolumn{2}{|l|}{$\begin{array}{l}\text { Family members } \\
\text { (person) }\end{array}$} \\
\hline Gender & & 0 & $3.5 \%$ \\
\hline Women & $52.2 \%$ & 1 & $5.1 \%$ \\
\hline Men & $47.8 \%$ & $2-4$ & $52.2 \%$ \\
\hline & & 5 & $38.3 \%$ \\
\hline \multicolumn{4}{|c|}{ Functional position } \\
\hline $\begin{array}{l}\text { Assistant } \\
\text { professor }^{1}\end{array}$ & $32.2 \%$ & \multicolumn{2}{|c|}{$\begin{array}{l}\text { Responsible to help } \\
\text { family members to } \\
\text { study/work from } \\
\text { home. }\end{array}$} \\
\hline $\begin{array}{l}\text { Assistant } \\
\text { professor }^{2}\end{array}$ & $4.9 \%$ & Yes & $59.1 \%$ \\
\hline Professor & $18.3 \%$ & No & $40.9 \%$ \\
\hline
\end{tabular}

Source: Processed Primary Data, 2021

${ }^{1}$ Asisten Ahli; ${ }^{2}$ Lektor; ${ }^{3}$ Lecturer does not have an academic position (PERMENRISTEKDIKTI 164/M/KPT/2019)
The respondents confirmed that the most popular application to carry out online classes are video conference platforms such as Zoom and Google Meet as shown in Figure 1. More than half the respondents disclose that their respective institutions provide their own online learning systems. Before the pandemic, institutions have built e-learning platforms mainly to facilitate learning materials distributions and enable the process of giving and submitting assignments.

Three of the institutions in this study already have e-learning platforms prior to the pandemic. However, those institutions elearning platform needed to upgrade their server capacity because of the sudden surge of access increased when the work from home. began in Indonesia in March 2020.

Other popular digital messaging applications and education web service (Google Classroom). A few lecturers also utilize voice conference application (Discord), uploading their lecture video on YouTube, as well as conducting live streaming on social media platforms.

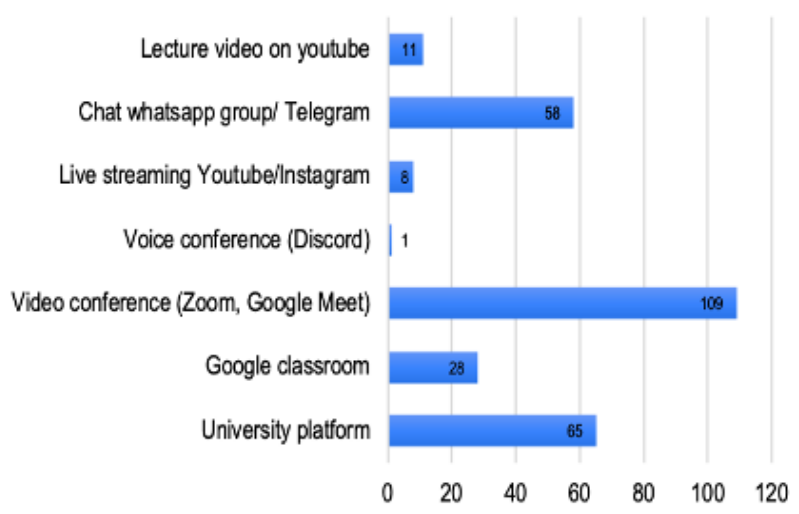

Figure 1. Teaching Method during Work from home.

Source: Processed Primary Data, 2021

Results about working conditions and requirements for lecturers are shown in Figure 2. 


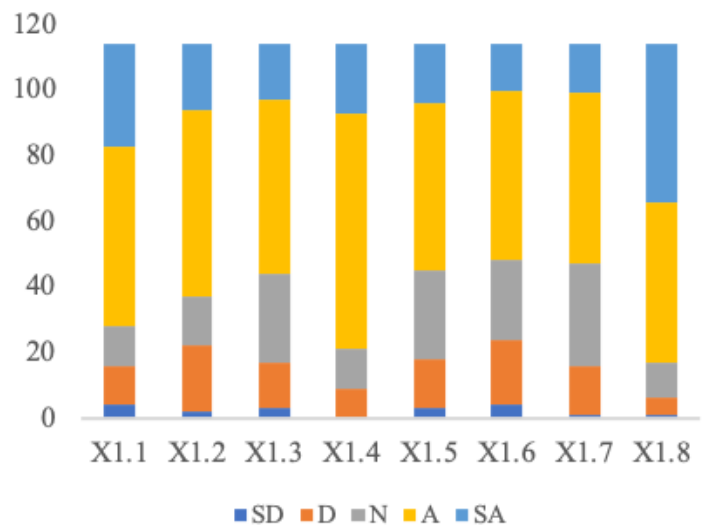

Figure 2. Working Conditions and Job Requirements

Source: Processed Primary Data 2021

The majority of respondents agree that they have adequate space to work from home. (X1.1). The respondents acknowledge that the majority agree with seldomly experience failure internet connection (X1.2), they agree that they have sufficient furniture, gadgets, sound systems and other tools to support them work-from home (X1.3) and the vast majority of respondents agree that they have access to information and tools required to work from home. (X1.4). The majority of respondents agree that their respective institutions provide sufficient communication channels (X1.5) and their institutions provide additional trainings to conduct work from home. (X1.6). Most respondents also agree that need of more training to use ICT tools (X1.7) and have participated in more meetings compared to before the pandemic (X1.8).

The result of lecturers' opinion about their ability to manage time and task during work from home. is shown in Figure 3.

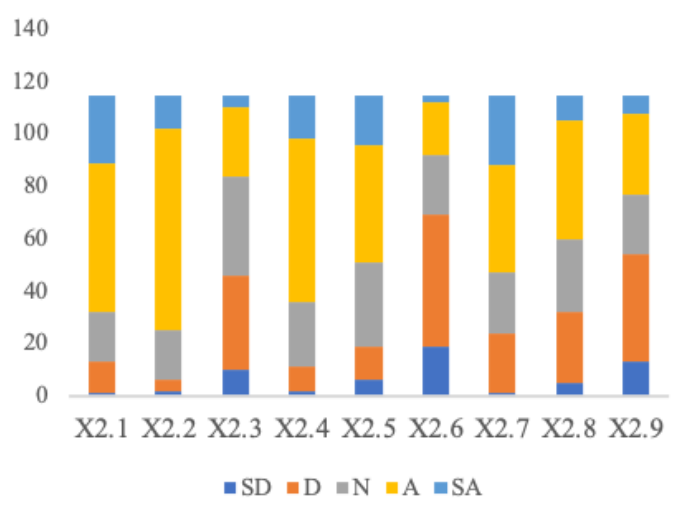

Figure 3. Time and Task Management Source: Processed Primary Data 2021
The majority of respondents believe that they can separate time between work and family (X2.1) even though they have tended family issues during work-hours (X2.2). Lecturers are more inclined to disagree with feeling hard to maintain work motivation during business hours (X2.3) and have set aside personal time when they need to (X2.4). A larger number of respondents feel more focused working in office (X2.5). Most respondents have worked on weekends (X2.6) and feel the current workload is bigger than before the pandemic (X2.7). More respondents agree that they are able to maintain same consistent work schedule (X2.8) and disagree with having time management problem (X2.9).

The outcome about work-related stress is illustrated in Figure 4.

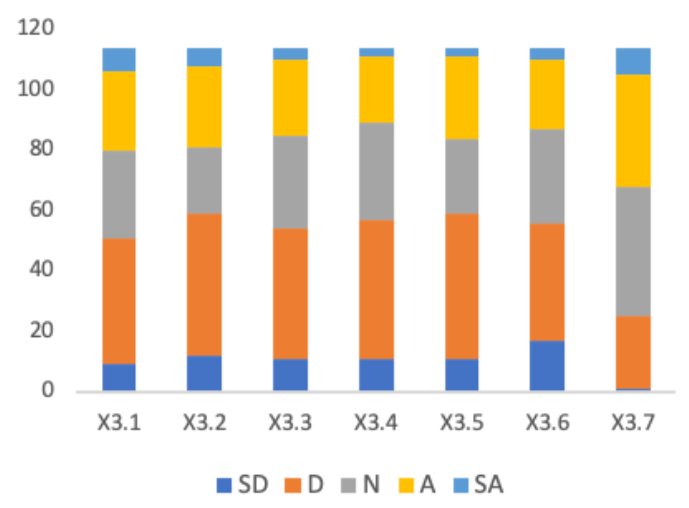

Figure 4. Work Related Stress

Source: Processed Primary Data 2021

The majority of respondents disagree that during work from home. they feel less patient (X3.1), more easily angered (X3.2), complain more frequently (X3.3), having "burn-out" syndrome (X3.4), and more sensitive to work demand (X3.5). In general, a larger number of lecturers disagree that work from home. make them more stressed than usual (X3.6). In addition, the majority feel neutral about needing more free time (X3.7).

The lecturers answer about their performance at work during work from home. is depicted in Figure 5. 


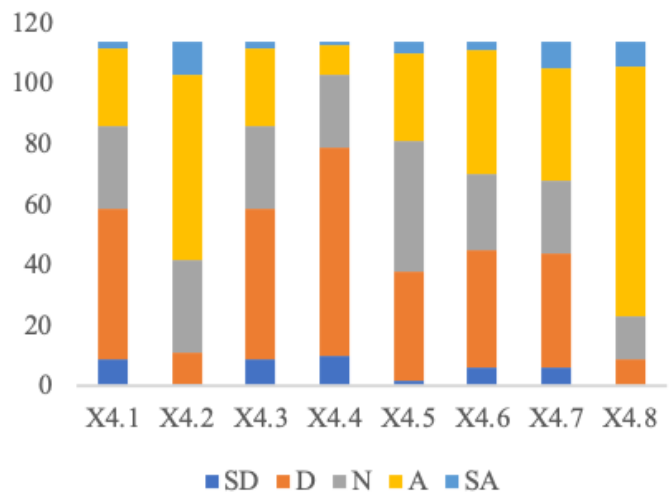

Figure 5. Performance at Work

Source: Processed Primary Data 2021

An overwhelming majority disagree to the notion of decrease in work performance (X4.1), experience difficulties using certain digital tools (X4.3), and disagree with experience difficulties adapting to work in "new normal" (X4.4). The majority of lecturer are confident they possess sufficient digital skill prior to the pandemic (X4.2). More respondents are neutral towards contacting their supervisor daily (X4.5). A larger number of respondents are leaning towards agreeing that noises at home affect their work quality (X4.6) but disagree to being distracted by digital entertainments (X4.7). Despite not seeing their coworkers as much as before the pandemic, an overwhelming majority of lecturers in this research agree that they still feel integrated with their coworkers albeit virtually (X4.8).

The lecturers' proclivity or preference towards work from home. in the future after the pandemic ended is shown in Figure 6.

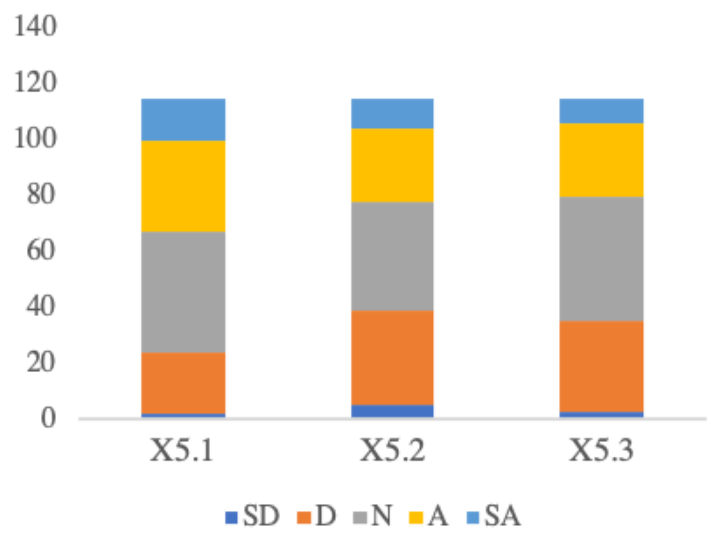

Figure 6. Decision to Work from home. in the Future

Source: Processed Primary Data 2021
It can be seen that there are less lecturers who agree compared with ones who are neutral and disagree about continue to work from home. in the future (X5.1). More are also neutral and disagree with preferring to keep work from home. if their institutionsof-employment allow (X5.2) and with able to show better performance when working from home (X5.3).

\section{Working Conditions and Requirements}

Nicholson and Baruch (1997) stated that work from home. requires available physical space. This study reveals that the majority of lecturers feel they have the space they needed to work conveniently at home. However, this study does not align with the findings of Ipsen et al (2021) that argues work from home. means having to work within adequate tools. In terms of teaching obligations, the current ICT technology is sufficed to enable people to work from home. easily.

The findings in Figure 2 (X1.2, X1.3, $\mathrm{X} 1.4$, X1.5) confirm that ICT has helped workers in many subjects to work from home. with digital and mobile applications. Olson (1983) argues that office environment serves to focus attention on work, including office furniture and décor. Since the majority of respondents are satisfied with their home environment during the work from home. period, it could be assumed that their home environment and décor has served to focus the lecturer's attention on work.

Although the previous studies find that working from home are better for reading literature, working and analyzing lecturers' data and manuscript (Aczel et al., 2021), this study finds that academic work can function to some extent with the current digital tools from home. Results of X1.5 and X1.6 confirm the findings of Vyas and Butakhieo (2020) that in order to work from home. efficiently, employees require proper trainings. 


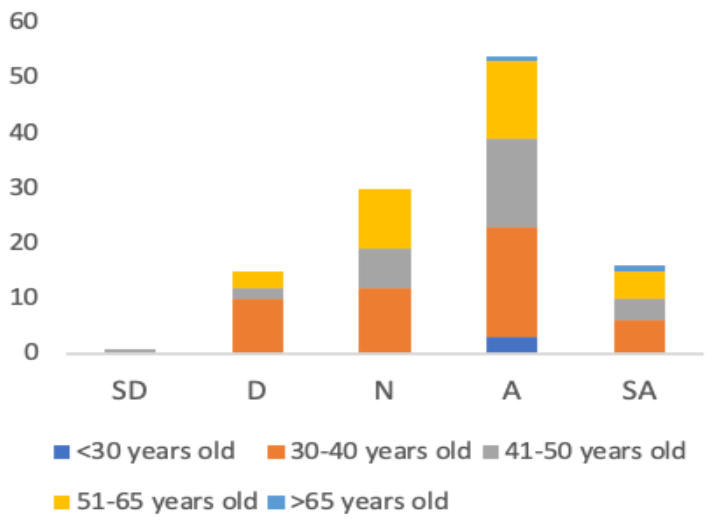

Figure 7. Perceived Need for Training to Utilize Additional Digital Tools

Source: Processed Primary Data 2021

This study also confirms that lecturers are required to adapt speedily to utilize technology in new and creative ways (Waizenegger et al., 2020) as they agree that they do feel the need of more training to use ICT tools (X1.7). Figure 7 shows that regardless of the age, most lecturers believe they need addition training in order to use digital tools more effectively and in more creative ways.

During the work from home. period, many workers find themselves participating in more meetings, albeit virtually, compared before the pandemic (Kost, 2020). The majority of the lecturers in this study agree to this notion (X1.8).

\section{Time and Task Management}

According to Lakien (1973), time management is the process of determining individual needs and wants and then sorting them according to their level of importance. On the other hand, Riss et al (2005) defines task management as a process to help individuals reach their goals, or for a group of individuals to collaborate and share knowledge in order to achieve a collective purpose.

Issues with work from home. such as the separation between work and family concern and distractions at home were asked to the respondents. Slightly different with the previous study, in this research, the majority of the respondents agree that they are able to separate time between work and family (X2.1). However, the majority also agrees that they have tended to family issues during working hours (X2.2). Since most lecturers do not teach all day from morning until noon, this could be the reason they believe they are able to separate home and professional time even though they have taken care of their family during work hours. Other duties for lecturers such as research and community service are also arranged flexibly according to the lecturer's preference and this has been the norm long before the pandemic.

More lecturers also lean towards agreeing that they feel more focus working in office (X2.5). These results confirms that work from home. make the separation of lecturers' work and family to become vague and lecturers can focus better when working in office.

However, more lecturers tend to disagree and strongly disagree with the notion "I feel hard maintaining work motivation during business hours" compared than the one who agree or feel neutral towards it (X2.3). Larson, Vroman, \& Makarius (2020) argues that work motivation could decrease during work from home. in the Covid-19 pandemic. On the other hand, there is another recent study that concluded working-from-home increases work motivation (Susilo, 2020). This particular result shows that work from home. did not lead to being feeling demotivated to work, which aligns with the findings of Susilo (2020). Although working and domestic responsibility intertwined, lecturers could still sustain their motivation to work.

On the task management aspect, most lecturers agree that their current workload is bigger than before the pandemic (X2.7). This specific result verifies Kost's (2020) suggestions that workers work more compared before the work from home. period.

Moreover, the majority of respondents agree that they work weekends (X2.6), but are able to maintain same consistent work schedule (X2.8). They also disagree with the notion of having time management problem (X2.9). These three notions suggests that the lecturers in this research have been able to 
manage their time to work from home. and able to maintain same consistent work schedule. This results are aligned with ones in the previous study, where work from home. means longer workhours and workers experience difficulty to take a break from work even on weekends (Heijstra \& Rafnsdottir, 2010; Hill et al., 1998).

However, it is important to note that lecturers in general work according to their teaching schedule, which is usually different each semester. Lecturers in Makassar, specifically those without additional administrative positions, are not obligated to work inside the campus in traditional 9-5 manner. For this reason, they are arguably have already accustomed to flexible work hours and outside the formal office environment before work from home. become mandatory during the pandemic. In consequence, the shift of work-from-office to work from home. for lecturers are not as dramatic nor as difficult to adapt to compared with workers in different fields or in different locations.

They also do work from home. not because lecturers chose to do it, but because it is enforced by the government due to the Covid-19 pandemic. The mandatory nature of this policy could have an affected the way lecturers and workers reacted to it, which future researches could look into.

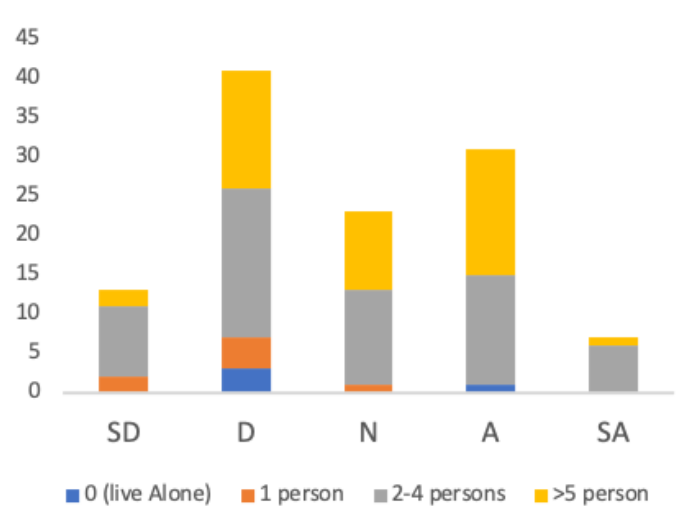

Figure 8. "I experience time management problem" Sorted by Number of Household Members

Source: Processed Primary Data 2021

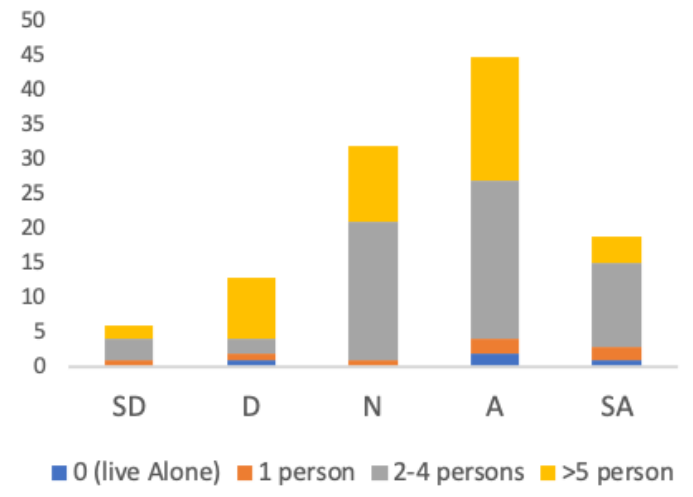

Figure 9. "I feel more focused working in formal office environment" Sorted by Number of Household Members

Source: Processed Primary Data 2021

As exhibited by Figure 8, people who do experience time management problems are ones who live with more than 2 family members. However, Figure 9 shows that even people who live alone or with only one other person, also feel they can focus to work more in a formal office environment.

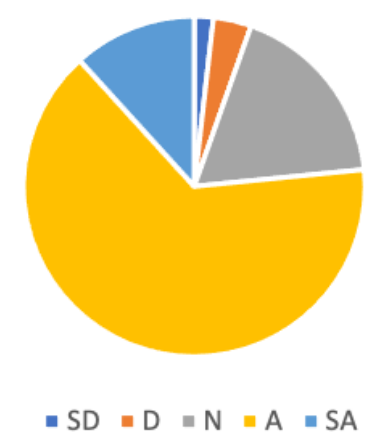

Figure 10. "I have Tended to Family Issues during Work Hours" and Have Household Members

Source: Processed Primary Data 2021

Figure 10 shows that the majority people who live with other household members (not living alone) have tended to family members during work hours. This proves the findings of Aczel et al (2021) in which working-from-home means facing distractions from other family members.

\section{Work Related Stress}

At the time this research was conducted, lecturers have experienced one year of work from home. . Occupational stress is commonly applied to factors related to work 
(Yongkang, Weixi, Yalin, Yipeng, \& Liu, 2014).

Even though previous studies suggested that teaching is a challenging profession, strenuous, and comes with high pressure (Antoniou, Ploumpi, \& Ntalla, 2013; Cascio et al., 2014; Herman, Prewitt, Eddy, Savale, \& Reinke, 2020; Kim, Shin, Tsukayama, \& Park, 2020; Ruggieri, Iervolino, Mossi, Santoro, \& Boccia, 2020; Zurlo, Pes, \& Capasso, 2013), Figure 4 reveals that the majority of respondents do not experience work related stress caused by work from home.

Incidents such as feeling lest patient (X3.1), feel angry more easily (X3.2), complain more frequently (X3.3), experiencing "burn-out" syndrome (X3.4), feeling more sensitive to work demand (X3.5), feeling more stressed than usual (X3.6) are all found seldomly occurred to the lecturers in this research.

These findings are aligned with previous studies by Moretti et al (2020) and Subramaniam (2020) whom found most academics do not experience increase in stress during work from home. . They also confirms the findings previous researches where work from home. resulted in decreased work related stress (Nicholson \& Baruch, 1997; Vyas \& Butakhieo, 2021).

Stress will arise when the job demand feels burdensome, exasperating, and exceeding the adaptability of an individual. As a consequence, it leads to decrease in work productivity (Krikcaldy, Levine, \& Sheperd, 2000). Zaki et al (2016) found that $61 \%$ of academics experience moderate level stress as a result of prolonged working hours, as well as increase in workload and responsibilities. However, the preponderance remarked that they are able to maintain consistent work schedule (X2.8), meaning they do not undergo extra working hours. Confirming the findings of Vyas and Butakhieo (2020) about work from home. means more rest, the respondents agree do not need more free-time during work from home. (X3.7).

In addition to decreasing the risk of spreading the virus, lecturers seem benefitted from the work from home. policy, as they do not get more stressed by work. However, further studies are needed to examine how this policy affected the student's learning quality.

The cause of stress can come from role characteristics, including role conflict, role ambiguity, and role overload (Widmer, 1993). In contrary with the study by Zaki et al (2016) and Widmer (1993), by comparing findings in Figure 3 and Figure 4, this study discovers that although the majority of respondents undertake more workload during the pandemic, they do not experience "burn-out" syndrome nor feeling more stressed out than usual.

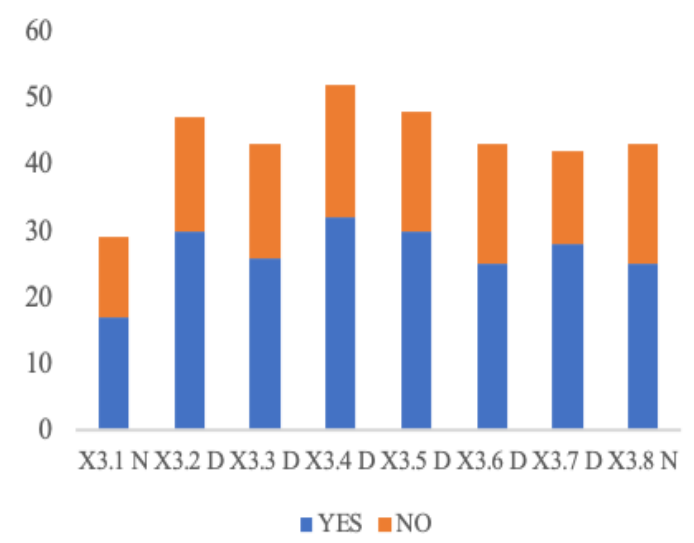

Figure 11. Work-Related Stress with Responsibility to Help Family Members with Online Learning

Source: Processed Primary Data 2021

The lecturers who do expressed feeling more stressed-out, less patient, more easily angered, and complain more during the pandemic are those who have more family members) and have the responsibility to help family members with online learning compared with those who live alone (Figure 11). Furthermore, lecturers who do desired for more free time are married and have the responsibility with family members with remote studying.

\section{Performance at Work}

The sudden shift from working from the office to work from home. was usual as well as mandated by the government. The lecturers were asked to assess their own work performance with questions in Table 1. 
Mitchell (2017) suggested that working outside a formal office environment can result in lack of support and visible leadership as well as having less social interaction when isolated and detached form the workplace. Meanwhile, Susilo (2020) finds that work from home. does not necessarily increase or decrease job performance of workers.

This study finds the majority of respondents believe work from home. has not negatively affect their job productivity (X4.1), albeit not having daily contact with supervisors (X4.5).

According to Nicholson and Baruch (1997), work from home. is suitable with highly autonomous professions, where the job is complex and feature high discretion. A lecturer job is not one which need intense supervision. There are control tools, such as Lecturer Workload (Indonesian: Beban Kerja Dosen / BKD), teaching attendance weekly report, students satisfaction survey, and many more. However, most head of department or study program does not check each lecturer one by one every day, even before the pandemic.

Since most of the lecturers already possess the required ICT or digital skills prior to the pandemic (X4.2), they do not experience difficulties to utilize online learning tools (X4.3), nor struggle to adapt to work in "new-normal" conditions (X4.4). This outcome confirms Nie \& Erbring (2002) and Purwanto (2020) which digital technology and mobile applications helped workers in many fields to do work from home. with certain ease.

Work from home. proved to sidetrack lecturers to some extent, for example household noises (X4.6) and digital distractions (e.g., entertainment and social media which are accessed with the same gadget used to work) (X4.7). Digital communications tools such as laptop and smartphone could be a double-edged sword since it can be used both for work and entertainment. While using the same laptop to work, lecturers can be tempted to not work and have leisure time instead. Previous studies suggested the two main challenges of work from home. are distractions at home and decrease of work motivation (Larson et al., 2020; Purwanto et al., 2020). Although this study confirms the first suggestion that work from home. comes with many distractions, but the findings in Figure 3 shows that the majority of lecturers feel neutral about being demotivated.

Although Aczel et al (2021) observed that working in an office environment is better for integrating with colleagues, an overwhelming majority of lecturers in this research finds that they still feel integrated with their team/colleague despite having to do it virtually. The many social media tools available make this possible.

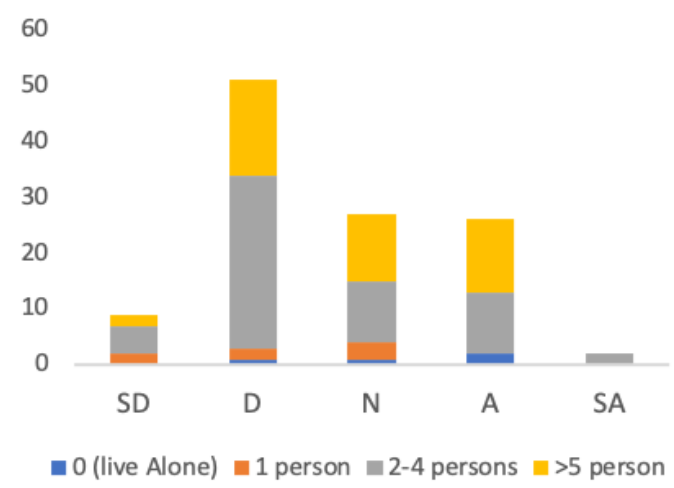

Figure 12. "I feel my work performance decrease during the pandemic" Sorted by Number of Household Members

Source: Processed Primary Data 2021

Unsurprisingly, analysis results in Figure 12 shows that lecturers with more family members at home feel that they work productivity decrease during the pandemic.

60

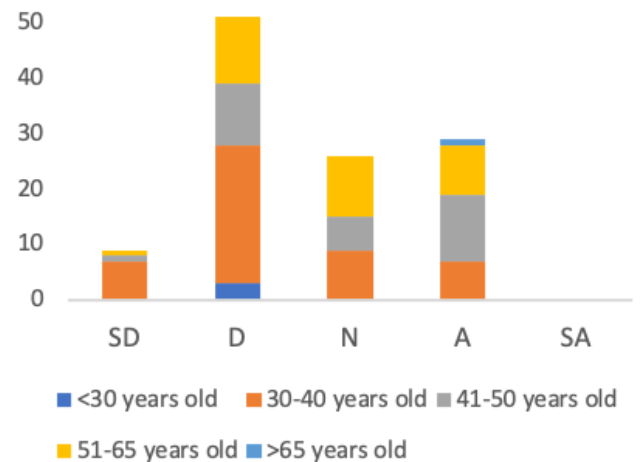

Figure 13. "I experience difficulties utilizing certain digital tools" Sorted by Age Source: Processed Primary Data 2021 


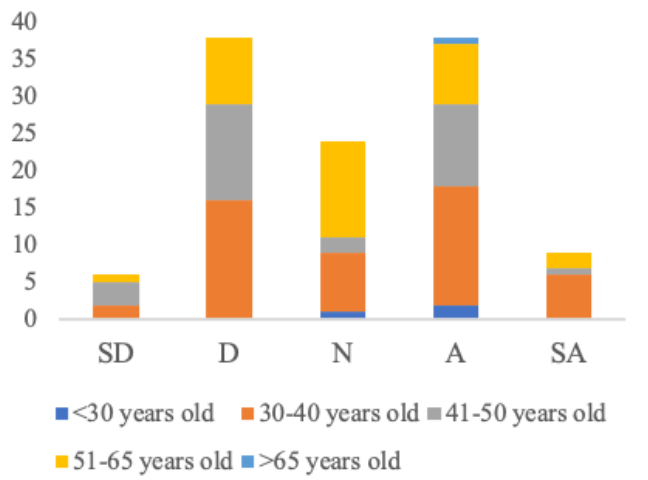

Figure 14. "While working-from-home I often get distracted by digital entertainments" Sorted by Age

Source: Processed Primary Data 2021

Figure 13 shows that lecturers age more than 51 years old do not believe that they experience difficulties utilizing certain digital tools. Meanwhile, lecturers who do agree to getting distracted by digital entertainments while working from home are more in the under 40 age group, as shown in Figure 14.

\section{Decision to Work from home. in the Future}

Going forward, the lecturers in this research are neutral towards work from home. in the future (Figure 6). Despite the fact that $25 \%$ respondents agree with work from home. policy in the future, $30 \%$ prefers face-to-face education process. Although most lecturers in study feeling happier working-from-home (Figure 4) and seldom go to the office anymore during the pandemic (Table 2), they actually feel more focused to work in office settings compared to the current situation (Figure 3). This is reflected in Figure 6 where the more than half respondents do not prefer work from home. in the future. This result is different with the findings of Aczel et al (2021) where the majority of academics are willing to do more work from home in the future than they did before the pandemic.

For lecturers who have spouses and kids, there are more respondents whom prefer to work in the office compared to those whom prefer keep working-from-home (Figure 15).
In hindsight, age difference and marital status does not affect work from home. preferential. In Malaysia, flexible work arrangement is more preferred by working women age 30-39 years old who has married (A. G. Subramaniam, Overton, \& Maniam, 2015).

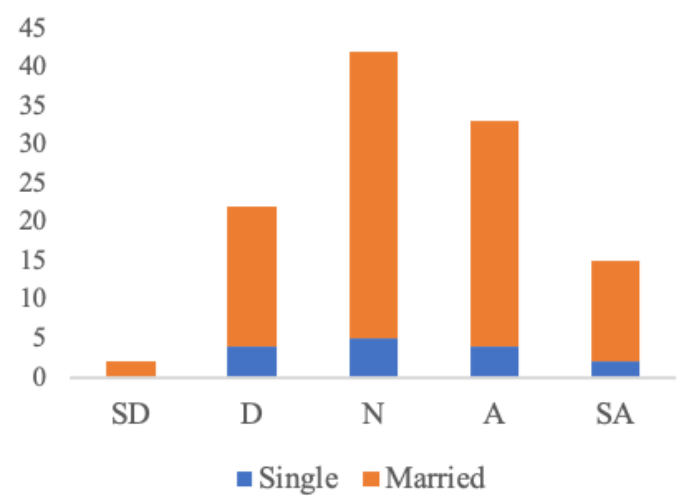

Figure 15. "I am interested to continue work from home. in the future" Sorted by Marital status

Source: Processed Primary Data 2021

Moreover, women with high education degree are tend to prefer flexible working arrangement than women without high education degree (Subramaniam, Overton, \& Maniam, 2015). Figure 16 confirms that highly educated women such as lecturers prefer to keep working-from-home if their institutions allow.

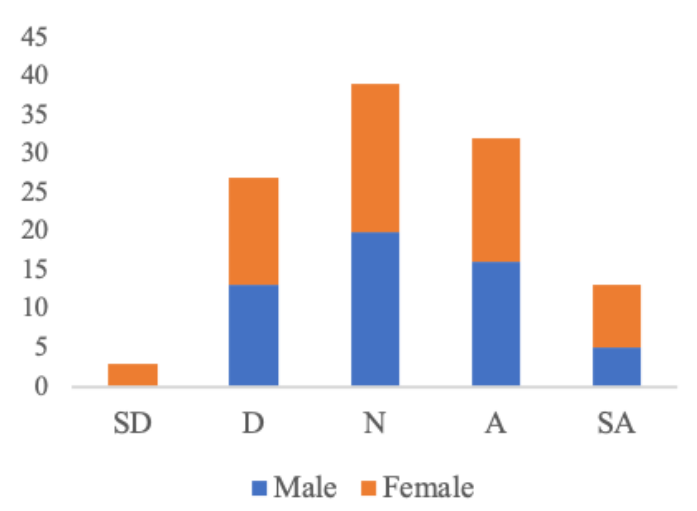

Figure 16. "I prefer to keep working-from-home if my institution allow" Sorted by Gender Source: Processed Primary Data 2021 


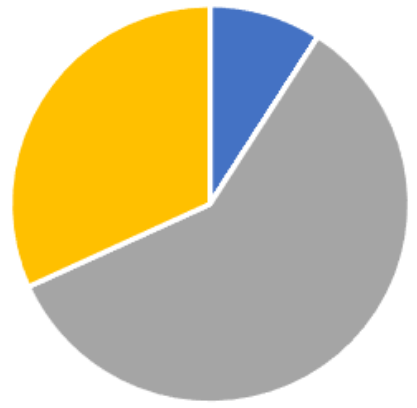

- 0 (live Alone) - 1 person = 2-4 persons = >5 person

Figure 17. "Disagree to Continue Work from home. in the Future" sorted by Number of Household Members

Source: Processed Primary Data 2021

There are individual differences in deciding about continuing work from home. in the future, after the pandemic ends. Figure 17 showcases that lecturer whom disagree to continue work from home. in the future are mostly people who live with many household members.

The work from home. policy for academics in Makassar came with its many benefits and challenges. Under the pandemic circumstances, academics in this research show that their working conditions at home were acceptable and they have sufficient working space at home, adequate ICT tools and facilities, adequate internet connections. They also indicate that despite already having necessary skills to operate digital tools to work from home. , most academics state they still needed trainings from their perspective institutions to maximize its utilization. Institutions involved in this research did provide trainings for its lecturers, especially to use the university online learning platform. Lecturers in this study indicate that they do not have daily contact with their supervisor, but still integrated with their team and colleagues through digital communication tools.

This research finds academics were capable of managing their time and task during work from home. . In contrast with previous studies, academics in this research are able to separate time between family and work, even those whom has more family members at home and those with responsibility to help their family members to do online learning. Academics do not experience much time management problem and are able to maintain same consistent workhours.

This research also reveals that work from home. policy during the Covid-19 pandemic was received by academics as a positive thing. Although academics indicate that during work from home. they need to attend more meetings and were given bigger workload, they do not experience burn-out syndrome nor stress increase. In addition, they indicate that despite having to work on weekends from time to time, they do not need more free time.

Lecturers in this study believe that work from home. does not affect their work performance negatively. Those who do experience performance decrease are ones with more than 5 family members. This research demonstrates that despite having many family members, most lecturers are able to continue their work performance and they are capable of organizing for work from home.

In spite of the fact academics in this research find conditions and circumstances of working-from-home as acceptable, more academics prefer to go back to work from office in the future. Lecturers want to do work in office settings as before the pandemic, but they do would like to spend more time working-from-home indicating preference for hybrid working process, which is a combination of work from office and work from home.

However, this study is limited because experience may vary to professions. Comparisons made in this study with previous study need further research due to the nature of lecturers from different field of study. Needless to say, this research cannot be assumed to indicate all academics in all fields of study. Lecturers from certain research fields, such as chemistry, fisheries, etc, need more time to work directly in field or laboratories. Lecturers from medical and pharmacy faculty in particular, which are obligated to carry their responsibilities in 
health workers during the pandemic, cannot work from home. fulltime. Other factors that may contribute to the variables such as phycological conditions, lecturers with additional administrative responsibilities, individual characteristics (integrity, initiatives, etc) should be explored more in the future researches.

\section{Conclution}

The study discovers that lecturers find the conditions of work from home. to be acceptable, they are able to organize their task and time to some extent, and it does not affect their work performance and does not have a negative impact on their stress level. In the future, the lecturers will feel neutral about work from home. after the pandemic subsidence. More are leaning towards going back to work in office settings, but open to do hybrid-working, which is a combination of work-from-office and work from home. .

\section{Acknowledgement}

Funding for this research was supported by UNHAS Novice Lecturer Research scheme by Universitas Hasanuddin Internal Research Grant.

\section{REFERENCES}

Aczel, B., Kovacs, M., Van Der Lippe, T., \& Szaszi, B. (2021). Researchers working from home: Benefits and challenges. PLoS ONE, 16(3 March), 1-9. https://doi.org/10.1371/journal.pone.02 49127

Belzunegui-Eraso, A., \& Erro-Garcés, A. (2020). Teleworking in the context of the Covid-19 crisis. Sustainability (Switzerland), 12(9), 1-18. https://doi.org/10.3390/su12093662

Bloom, N. (2014). T A Significant Improvement in Performance. (February). Retrieved from https://stayinthegame.net/wpcontent/uploads/2019/07/HBR-ToRaise-Productivity-Let-MoreEmployees-Work from home. .pdf

Delanoeije, J., Verbruggen, M., \& Germeys, L. (2019). Boundary role transitions: A day-to-day approach to explain the effects of home-based telework on workto-home conflict and home-to-work conflict. Human Relations, 72(12), 1843-1868.

https://doi.org/10.1177/0018726718823 071

Dizaho, E. kadarko, Salleh, R., \& Abdullah, A. (2017). Achieveing work life balance through flexible work schedules and arrangements. Global Business \& Management Research, 9(1), 455-465. Retrieved from http://search.ebscohost.com/login.aspx? direct $=$ true $\&$ AuthType $=$ shib $\& d b=$ th $\&$ $\mathrm{AN}=122717287 \&$ site $=$ eds-

live \&scope $=$ site $\&$ custid $=$ uphoenix

Faulds, D. J., \& Raju, P. S. (2021). The Work from home. Trend: An Interview with Brian Kropp. Business Horizons, 64, 2935.

https://doi.org/https://doi.org/10.1016/j. bushor.2020.10.005

Gurstein, P. (2001). View of Wired to the World, Chained to the Home: Telework in Daily Life. Vancouver: UBC Press.

Hair, J. F., Ringle, C. M., \& Sarstedt, M. (2013). Partial Least Squares Structural Equation Modeling: Rigorous Applications, Better Results and Higher Acceptance. Long Range Planning, 46(1-2), 1-12. https://doi.org/10.1016/j.lrp.2013.01.00 1

Hartig, T., Kylin, C., \& Johansson, G. (2007). The telework tradeoff: Stress mitigation vs. constrained restoration. Applied Psychology, 56(2), 231-253. https://doi.org/10.1111/j.14640597.2006.00252.x

Hasan, I. (2001). Pokok-pokok Materi Statistik I (Statistik Deskriptif). Jakarta: Bumi Aksara.

Heijstra, T. M., \& Rafnsdottir, G. L. (2010). The Internet and academics' workload and work-family balance. Internet and Higher Education, 13(3), 158-163. https://doi.org/10.1016/j.iheduc.2010.03 .004

Hickman, A., \& Robison, J. (2020). Is 
Working Remotely Effective? Gallup Research Says Yes. 2020, 6-8. Retrieved from

https://www.gallup.com/workplace/283 985/working-remotely-effective-gallupresearch-says-yes.aspx

Hill, E. J., Miller, B. C., Weiner, S. P., \& Colihan, J. (1998). Influences of the virtual office on aspects of work and work/life balance. Personnel Psychology, 51(3), 667-683. https://doi.org/10.1111/j.17446570.1998.tb00256.x

Ipsen, C., van Veldhoven, M., Kirchner, K., \& Hansen, J. P. (2021). Six key advantages and disadvantages of working from home in europe during covid-19. International Journal of Environmental Research and Public Health, 18(4), 1-19. https://doi.org/10.3390/ijerph18041826

Jackson, P. (1999). Virtual Working: Social and Organisational Dynamics. In Routledge. https://doi.org/10.4324/9780203064368 $-19$

Kelliher, C., \& Anderson, D. (2010). Doing more with less? flexible working practices and the intensification of work. Human Relations, 63(1), 83-106. https://doi.org/10.1177/0018726709349 199

KEMDIKBUD, R. I. (2020). SE Dirjen Dikti: Pembelajaran Selama Masa Darurat Pandemi. Retrieved from https://www.kemdikbud.go.id/main/blo g/2020/03/se-dirjen-dikti-pembelajaranselama-masa-darurat-pandemi-covid19

Klopotek, M. (2017). The advantages and disadvantages of remote work from the perspective of young employees. Organization \& Management Quarterly, Maria Curie-Sklodowska University, 40(4), 39. Retrieved from http://ezproxy.umuc.edu/login?url=https ://search.ebscohost.com/login.aspx?dire $\mathrm{ct}=$ true $\& \mathrm{db}=\mathrm{edb} \& \mathrm{AN}=133706845 \&$ site $=$ eds-live $\&$ scope $=$ site

Kost, D. (2020). You're Right! You Are Working Longer and Attending More
Meetings. Harvard Business School. Retrieved from https://hbswk.hbs.edu/item/you-reright-you-are-working-longer-andattending-moremeetings\#commentsAnchor\%0Ahttps:// hbswk.hbs.edu/item/you-re-right-youare-working-longer-and-attendingmore-meetings

Kramer, A. (University of I., \& Kramer, K. Z. (University of I. (2020). The potential impact of the Covid-19 pandemic on occupational status, work from home, and occupational mobility. Journal of Vocational Behavior, 119(January). https://doi.org/https://doi.org/10.1016/j.j vb.2020.103442

Lakien, A. (1973). How to Get Control of Your Time and Your Life. New York: New American Library.

Larson, B. Z., Vroman, S. R., \& Makarius, E. E. (2020, March). A Guide to Managing Your (Newly) Remote Workers. Harvard Business Review.

Lidwina, A. (2021). 52\% Pekerja Global Bekerja dari Rumah selama Pandemi Covid-19 | Databoks. Retrieved from katadata.co.id website: https://databoks.katadata.co.id/datapubli sh/2021/01/06/52-pekerja-global-

bekerja-dari-rumah-selama-pandemicovid-19

McDonagh, S. (2021, October). Which countries in Europe are looking at making remote working a legal right post-COVID? Euronews.Com. Retrieved from https://www.euronews.com/next/2021/1 0/03/which-countries-plan-to-offerremote-working-as-a-legal-right

Mitchell, D. (2017). 50 Top Tools for Employee Engagement: A Complete Toolkit for Improving Motivation and Productivity. Kogan Page: London.

Nicholson, N., \& Baruch, Y. (1997). Home, sweet work: Requirments for effective home working. Journal of General Management, Vol. 23, pp. 15-30.

Nie, N. H., \& Erbring, L. (2002). INTERNET AND SOCIETY: A PRELIMINARY 
REPORT (Vol. 1). Retrieved from http://www.itandsociety.org

Purwanto, A., Asbari, M., Fahlevi, M., Mufid, A., Agistiawati, E., Cahyono, Y., \& Suryani, P. (2020). Impact of Work From Home (WFH) on Indonesian Teachers Performance During the Covid-19 Pandemic: An Exploratory Study. International Journal of Advanced Science and Technology, 29(5), 6235-6244.

Riss, U. V., Rickayzen, A., Maus, H., \& van der Aalst, W. M. P. (2005). Challenges for Business Process and Task Management. Journal of Universal Knowledge Management, O(2), 77-100. https://doi.org/10.1108/1463715091100 3793

Sheng, W. H. (2020). Coronavirus disease 2019 (covid-19). Journal of Internal Medicine of Taiwan, 31(2), 61-66. https://doi.org/10.6314/JIMT.202004_3 1(2). 01

Stoller, K. (2021, January). Never Want To Go Back To The Office? Here's Where You Should Work. Forbes.Com, 1-11. Retrieved from https://www.forbes.com/sites/kristinstol ler/2021/01/31/never-want-to-go-backto-the-office-heres-where-you-shouldwork/?sh=ec3d53f67127

Subramaniam, A. G., Overton, B. J., \& Maniam, C. B. (2015). Flexible Working Arrangements, Work Life Balance and Women in Malaysia. International Journal of Social Science and Humanity, $5(1)$, 34-38. https://doi.org/10.7763/ijssh.2015.v5.41 7

Sugiyono. (2007). Metode Penelitian Kuantitatif, Kualitatif, dan $R \& D$. Bandung: Alfabeta.

Susilo, D. (2020). Revealing the Effect of Work from home. on Job Performance during the Covid-19 Crisis: Empirical Evidence from Indonesia. Journal of Contemporary Issues in Business and Government, $26(01)$. https://doi.org/10.47750/cibg.2020.26.0 1.002
Umah, A. (2021). Target Vaksinasi Covid Masih Jauh, RI Genjot Jadi 1 Juta / Hari. Retrieved June 15, 2021, from cnbcindonesia.com website: https://www.cnbcindonesia.com/news/2 0210601185920-4-249826/targetvaksinasi-covid-masih-jauh-ri-genjotjadi-1-juta-hari

Versey, H. S. (2015). Managing work and family: Do control strategies help? Developmental Psychology, 51(11). https://doi.org/10.1037/a0039607

Vyas, L., \& Butakhieo, N. (2021). The impact of working from home during COVID19 on work and life domains: an exploratory study on Hong Kong. Policy Design and Practice, 4(1), 59-76. https://doi.org/10.1080/25741292.2020. 1863560

Waizenegger, L., McKenna, B., Cai, W., \& Bendz, T. (2020). An affordance perspective of team collaboration and enforced working from home during COVID-19. European Journal of Information Systems, 29(4), 429-442. https://doi.org/10.1080/0960085X.2020. 1800417

Walpole, R. E. (1995). Pengantar Statistika Edisi Ke-3 by Ronald E. Walpole (3rd ed.). Retrieved from https://pingpdf.com/pdf-pengantarstatistika-edisi-ke-3-by-ronald-ewalpole-goodreads.html

WHO. (2020). Coronavirus disease (COVID19): How is it transmitted? Q\&A Detail, (July 2020), Coronavirus disease (COVID-19) pandemic. Retrieved from

Widmer, C. (1993). Role Conflict, Role Ambiguity, and Role Overload on Boards of Directors on Nonprofit Human Service Organizations. Nonprofit and Voluntary Sector Quaterly, 22(4), 339-356.

Yongkang, Z., Weixi, Z., Yalin, H., Yipeng, X., \& Liu, T. (2014). The Relationship among Role Conflict, Role Ambiguity, Role Overload and Job Stress of Chinese Middle-Level Cadres. Chinese Studies, 03(01), 8-11. 